\title{
REGULATING TEENAGE ABORTION IN THE UNITED STATES: POLITICS AND POLICY
}

\author{
CAROL SANGER*
}

\section{ABSTRACT}

Thirty-four US states currently require pregnant minors either to notify their parents or get their consent before having a legal abortion. The Supreme Court has upheld the constitutionality of these statutes provided that minors are also given an alternative mechanism for abortion approval that does not involve parents. The mechanism used is the 'judicial bypass hearing' at which minors persuade judges that they are mature and informed enough to make the abortion decision themselves. While most minors receive judicial approval, the hearings intrude into the most personal aspects of a young woman's life. The hearings, while formally civil in nature, can be punitive in tone. Parental involvement statutes are often couched in the language of family communications and protecting minors. They are politically popular because they offer politicians the chance to be pro-life, pro-choice, and pro-family all at once. This paper argues that parental involvement statutes are less concerned with developing nuanced policies to improve the quality of teenage health or decision making than with securing a set of political goals aimed at making abortion harder to get, restoring parental authority, and punishing girls for having sex.

\section{INTRODUCTION}

What does it take for an unmarried pregnant minor - a girl under 18 - to get an abortion in the United States today? Putting aside such practical problems as finding a doctor in regions of the country where there are few abortion providers, what does the law have to say about minors and abortion? Over 44 of the 50 American states have answered the question by enacting 'parental involvement' laws. ${ }^{1}$ These are statutes that require a doctor either to notify a pregnant minor's parents or obtain their written consent before performing an abortion. In certain respects, the requirement makes sense. As with other important decisions in a teenager's life, parents may well be the best people to help their

\footnotetext{
* Barbara Aronstein Black Professor of Law, Columbia Law School, 435 West 116th St, New York. esanger@law.columbia.edu
}

International Journal of Law, Policy and the Family, Vol. 18, No. 3,

(C) Oxford University Press, 2004; all rights reserved 
daughter think through the complexities of resolving an unplanned pregnancy. Most teenage girls who still live with their parents talk over such decisions with at least one parent even in the absence of a statutory requirement. ${ }^{2}$ In addition to parental guidance or support, it is further argued that unless parents know their daughter has had an abortion they will be unable to provide proper medical care, should any post-procedure complications arise. These concerns are commonly incorporated into explanatory 'Legislative Findings' set out at the beginning of parental involvement statutes. Alaska's is typical. It recites its purposes to be:

protecting minors against their own immaturity; fostering the family structure and preserving it as a viable social unit; protecting the rights of parents to rear children who are members of their household; and protecting the health of minor women. ${ }^{3}$

But what if an unmarried pregnant minor doesn't want her parents to know that she is pregnant or that she intends to have an abortion? Depending on a number of factors - parental religious beliefs, the circumstances of home life, or just ordinary tensions between parents and teenagers, especially when sex is involved - a pregnant minor may not want to involve her parents in her decision at all. She may be afraid to risk their disapproval or rejection; if she lives in a state that requires consent, she may be afraid to risk their refusal. In cases where the pregnancy results from incest, the minor may have heightened concerns about revealing her circumstances. In addition, as is explained more fully below, as a matter of US constitutional law the decision to terminate a pregnancy cannot be subject to the veto of any third party, even a parent. ${ }^{4}$ In light of these considerations and constraints, parental involvement statutes provide the pregnant teenager with an alternative. Instead of talking to her parents, she may go to court and petition a judge for permission to obtain an abortion. The hearing at which she makes her case is called a 'judicial bypass hearing', because it provides an 'end run', or bypass, around parental consent or notice.

In this paper, the origins and implementation of this regulatory scheme - a highly legalistic response to teenage pregnancy resolution from the perspectives of law, politics, and family policy are discussed. It is argued that parental involvement statutes, while often couched in the language of family togetherness and child protection, are less concerned with developing sound or nuanced family policies in the area of adolescent reproduction than with securing a set of political goals aimed at thwarting access to abortion, restoring parental authority, and punishing girls for having sex. These goals are accomplished by requiring minors who seek to abort without parental consultation to participate in the judicial bypass hearing process as a condition to 
abortion. The lack of nuance in this arrangement is apparent from the scope of the statutes. The law applies not just to adolescents of 13 or 14, but to unmarried 16- and 17-year-olds as well, including those who no longer live at home and those who are already mothers. The sweep of coverage suggests from the start that parental involvement statutes focus not on adolescence as a stage of development but rather on minority as a site of control.

To situate the discussion in its distinctively legal setting, two background points are raised. The first is that the regulation of abortion in the US is largely a matter left to the states. Such matters as licensing abortion doctors and facilities, establishing requirements for informed consent, and funding abortions for poor women - as well as the determination regarding parental involvement for pregnant teenagers - are decided state by state. This means that the circumstances under which pregnant women and girls obtain abortions depend in part on where they live and whether they can travel. Second, while abortion regulation is left to the states, the right to abortion has been secured as a matter of federal constitutional law. In the 1973 case of Roev Wade, the US Supreme Court (SC) established that a protected right to privacy 'was broad enough to encompass a woman's decision whether or not to terminate her pregnancy'. ${ }^{5}$ This holding - protecting 'the right of a woman to chose to have an abortion before viability' - was affirmed in a 1992 case, Planned Parenthood of Pennsylvania v Casey. ${ }^{6}$ States may therefore regulate abortion as much as they like provided that the regulation does not create what Casey termed an 'undue burden' or substantial obstacle for women seeking abortion. With this structure in mind - a state regulatory system constrained by federal constitutional provisions - I turn specifically to the regulation of abortion for minors.

\section{THE LEGAL STATUS OF PREGNANT MINORS}

An early question left open by Roe was whether the language about a woman's decision to terminate a pregnancy applied to pregnant girls as well. On one hand, under the common law parents have long had the authority to decide what is best for their children in all areas of life, including most forms of medical care. ${ }^{7}$ There are a few statutory exceptions - drug use and sexually transmitted diseases, for example where from a health perspective the goal has been to encourage teenagers to get treatment. In most cases, however, parents - not their unemancipated minor children - rule. This principle is now a matter of constitutional significance: over the course of the twentieth century, parental authority to care for and to control children has been established as a protected liberty interest. At the same time, however, the Supreme Court has recognized that minors too have certain constitutional rights. ${ }^{8}$ Although under the US Constitution these rights 
are never quite equal to those of adults, minors nonetheless have been granted limited protections in such areas as criminal procedure, free speech, and, following a line of privacy cases, in aspects of procreative liberty such as the right to obtain contraception. ${ }^{9}$

The situation of pregnant minors forced a showdown between these competing interests. Were pregnant girls, like pregnant women, constitutionally protected in their decisions regarding abortion or did this decision properly fall within parental authority? Whose right prevailed? The answer was a compromise of sorts. In a 1979 case, Bellotti v Baird, the Supreme Court acknowledged the special importance of abortion for minors: 'there are few situations in which denying a minor the right to make an important decision will have consequences so grave and indelible'. ${ }^{10}$ Yet the Court held firm to its view that the rights of children, even teenage children, are not co-extensive with those of adults for three oft-cited reasons: 'the peculiar vulnerability of children, their inability to make critical decisions in an informed, mature manner, and the importance of the parental role in child-rearing' ${ }^{11}$ The Court then concluded that individual states may condition a girl's decision to abort on the consent of or notice to her parents. However, as with pregnant women, no one - not parents, not boyfriend, not whoever the father may be - may exercise a complete veto over a minor's informed decision to abort. ${ }^{12}$

But how were these conflicting principles - the minor's right not to be overruled and the parents' right to participate - to work in practice? In thinking through the answer, the Court took seriously the realities of teenage life. It recognized that informing parents about an intended abortion might well function as a de facto veto: 'young pregnant minors, especially those living at home, are particularly vulnerable to their parents' efforts to obstruct both an abortion and their access to court' ${ }^{13}$ Accordingly, the Court held that if a state requires parental involvement in a minor's abortion decision, it must also provide her with 'the opportunity - if she so desires - to go directly to a court without first consulting her parents'. ${ }^{14}$ The opportunity takes the form of the judicial bypass hearing, at which pregnant minors attempt to persuade local trial judges to waive parental notice or consent requirements and authorize the abortion. Thus each year thousands of pregnant teenagers learn, whether by going on-line, visiting a clinic or by teenage word of mouth, that if they want an abortion they must first have either a note from home or an order from court.

\section{A. The Hearings}

The judge at a bypass hearing must resolve two issues. As set out in Bellotti, he must first assess whether the minor is mature and informed enough to make a decision to abort. If he decides she is sufficiently mature, her petition must be granted and the minor may present it to 
doctor who can then treat her without the risk of penalty. If, however, the judge finds that the petitioning minor is not mature or informed enough to decide whether an abortion is right for her, he must then decide whether an abortion is nonetheless in her best interests. This second inquiry prevents the peculiar outcome that would otherwise result: a minor deemed too immature to make a decision about motherhood becomes a mother.

The structure of the bypass process is guided by two constitutionally imposed requirements. First, because the very point of the hearing is to avoid parental attention, the process is organized to secure the minor's anonymity so that her parents will not find out about her decision before (or after) the hearing. (The exception are pregnancies that result from rape or incest; these must be reported to local social services for investigation.) To conceal their names and identities, petitioners are given Anonymous or Jane Doe designations; the hearings are held in closed courtrooms or judicial chambers; court personnel are cautioned to treat documents with care. While such safeguards help protect the minor's privacy, serious practical problems remain. She must still appear in the public court house to get to her hearing and, if seen by neighbours or others, she must still be able to explain what she is doing downtown in the middle of a school day. ${ }^{15}$

The second constraint concerns speed. The entire process must be completed quickly so that if the bypass petition is granted, the abortion may take place within legal pre-viability time constraints. To make the process move smoothly, states provide minors with attorneys to help them prepare for the hearings. However, studies have shown that local court personnel in many states are often ill-equipped (and on occasion hostile) in providing assistance in starting the process. ${ }^{16}$ To make sure that judges themselves do not slow things down, several states provide that if the court fails to render a decision within the statutorily specified period of time (typically 48 hours), the petition is deemed granted.

How do minors fare in bypass hearings? While there are no comprehensive national statistics, it appears that almost all petitions are granted. A five-year study of Minnesota by-pass hearings revealed that out of 3,573 petitions, nine were denied, six were withdrawn, and 3,558 were granted. ${ }^{17}$ The Supreme Judicial Court of Massachusetts noted in 1997 that 'judicial approval is nearly a certainty'. ${ }^{18}$ Out of 15,000 cases in Massachusetts heard by the year 2000, only 13 were denied and 11 of those were reversed on appeal. ${ }^{19}$ Judges tend to fall into two categories: those who grant no petitions, and those who rubber stamp most. Those who grant none are often opposed to abortion on religious or moral grounds. Others may not be so much personally opposed to abortion as they may be politically savvy. State trial court judges in the US are usually elected to office; in the present political climate, any positive association with abortion - especially the abortions of daughters avoiding parents - 
is bad for one's campaign. ${ }^{20}$ In the other category, judges who regularly grant bypass petitions have testified how ill-equipped they feel themselves to be in assessing a pregnant minor's maturity or her best interests with regard to the question of abortion. Their practice is often to approve petitions unless they find the minor is ambivalent about her own wishes. ${ }^{21}$

But not all petitions are granted. An Alabama judge denied the petition of a 17-year-old on the grounds that 'petitioner's actions in becoming pregnant in light of sex education in the schools ... is indicative that she has not acted in a mature and well informed manner'. ${ }^{22}$ In Kansas, a judge denied the petition of a 15-year-old, noting that her level of maturity was 'admirable but not extraordinary'. ${ }^{23}$ An Ohio court denied the petition of a young woman who was days away from her 18th birthday on the grounds that her pregnancy alone indicated insufficient maturity. ${ }^{24}$ Another Alabama judge refused to find mature a 17-year-old high school graduate who supported herself with a full-time job and whose stepfather had threatened her mother if she consented to her daughter's abortion. In that case, the appellate court reversed the decision, holding that 'We can safely say, having considered the record, that, should this minor not meet the criteria for 'maturity' under the statute, it is difficult to imagine who would' ${ }^{25}$ In none of these cases did a court then decide that despite the determination of immaturity, an abortion was nonetheless in the minor's best interests.

While some of these denials were reversed on appeal, not all are appealed or reversed. The result is that some girls tell their parents; some travel to more congenial non-bypass states; and still others become mothers.

\section{B. Process as Punishment}

Many of the cases discussed above appear to be deliberate misapplications of law by judges who disapprove of abortion, or perhaps disapprove of pregnant young women who don't want to talk to their parents. Denials based on the personal views of the judge rather than the principled performance of judicial duties are deeply disturbing and excite our sense of injustice. I want to suggest, however, that injustice attaches even to the 'successful' cases where the petition is granted. My argument here is the hearings themselves - and not just their outcomes - are an improper use of law. For whatever the disposition of the petition, all minors who fear telling their parents about their pregnancy or their decision to abort must participate in the bypass hearing process, a process that creates its own set of harms.

The most immediate harm is physical. As the American Medical Association, the American College of Obstetricians and Gynecologists, and the American Academy of Pediatricians have all agreed, and 
repeatedly testified, the judicial bypass system delays the process of obtaining an abortion and delay is medically problematic. ${ }^{26}$ The delay is compounded particularly so for minors, who tend to be slow to recognize or confirm their pregnancies in the first place. Petitioning for a waiver, as well as litigating the denial on appeal, increases the likelihood that the more invasive methods of abortion are often necessary in later stages of pregnancy. Pregnant teenagers are sometimes aware of the medical consequences of delay. In a 2000 Texas case, the Jane Doe petitioner was nearly 18 when she discovered her pregnancy. Although she could have waited until her birthday and obtained an abortion without parental involvement, she chose instead to petition so that she could have the abortion at the earliest possible stage of her pregnancy. ${ }^{27}$ In granting Doe's petition before issuing a full decision, the Texas Supreme Court explained that its decision was based on ' $[\mathrm{T}]$ he record indicat[ing] both that Doe was entitled to a bypass and out of concern that any further delay would subject her to further risk.... We made our decision on the side of the minor's safety'. ${ }^{28}$

Bypass hearings also cause significant psychological distress. Testimony by judges who hear the cases and by the girls themselves leaves no doubt that the experience is one of dread, tension, and anxiety. ${ }^{29}$ This can be no surprise. Even before the law steps in, these young women are already pregnant, unmarried, and believe themselves isolated from their parents. Like pregnant women, teenagers must also weigh existing obligations and aspirations against the prospect of motherhood. Of course, adult women do not have to discuss these matters in front of a judge. They do not need to skip school as part of their decision-making process. And adult women do not have to tell either their parents or a judge that they have had sex. Parental consent and notice statutes require precisely this revelation and for many teenagers, fear of talking to parents may have as much to do with revealing their sexual activity as with announcing their pregnancy. ${ }^{30}$ Other reasons minors are reluctant to involve parents include the fear of being rejected, kicked out of the family home, or punished physically. ${ }^{31}$ There is also the fear, particularly of good girls, in disappointing their (formerly) trusting parents. In a number of cases, minors also express concern about the effect of their disclosure on their parents' marriage or on a depressed or overburdened parent's mental state, although such family-oriented concerns are often dismissed by courts as pretextual or trivial in nature.

If for any of these reasons a minor decides that she will not talk to her parents, she must prepare for a different ordeal: a hearing in court. This leads to a kind of injury distinctly legal in force and origin: the burden of forced speech. ${ }^{32}$ Bypass petitioners must testify as to the most private matters in a teenage life: the fact of sexual intercourse; the predicament of pregnancy; the structure or disarray of home life that make her believe she should not involve her parents; her views on motherhood; 
her success (or not) in life so far; and her idea of her future. Such revelations are intensely difficult for teenage girls, just as they would be for pregnant women who, at least since the pre-Roe days of hospital abortion review committees, have been spared such recitations. ${ }^{33}$ That only the judge and a few others are present in a bypass hearing does little to diminish the magnitude of the intrusion. Requiring these disclosures from vulnerable young women is a significant invasion of a minor's privacy. Whether or not such an invasion is a constitutional matter, it is a matter of basic decency: the kind of respectful treatment that all people should be able to expect from their governments. ${ }^{34}$

The successful bypass petitioner must be prepared to provide information not only about her grades and after-school jobs (so responsible! so mature!) but also about why she has rejected the good counsel of her parents as well as the alternatives of adoption or motherhood. But a Texas case from 2000 demonstrates that what matters is not thoughtful consideration of these issues but rather the conclusions that the minor has reached. In that case, the trial court denied the petition of a 17-year-old Jane Doe who had researched abortion and its alternatives and had consulted with several counsellors, including three teenagers who had been in the same situation (one had decided to abort and the other two were raising their children). She had also insisted on seeing the foetus on a sonogram screen in order to confront the reality of her decision as directly as possible. Despite the minor's engagement with the moral, medical, and practical dimensions of the decision, the trial court found that she was not sufficiently well informed because 'she did not understand the intrinsic benefits of keeping the child or of adoption'. 35

In short, judicial bypass hearings serve as a unique and rather clever form of punishment. They are intrusive, humiliating, and meant to punish. In urging this characterization, I recognize that many forms of legal processes may humiliate or appear to punish those who must participate in them. Hearings over competency, child custody, immigration marriage fraud, or drunk driving, for example, often demand testimony that is unpleasant for those involved. My concern is not, however, with humiliation or harassment that is incidental to a process but rather with the intentional use of legal process to punish in cases where the petitioner has committed no legal wrong. It is worth remembering that these pregnant teenagers are petitioners in a civil action. They are petitioners - there is no prosecutor; there is no defendant. (There is, however, a disturbing trend in Alabama, where some judges have begun to appoint guardians ad litem to represent the foetus; they have then been permitted to cross-examine the teenager about her decision and to call witnesses to testify about the consequences of the abortion for the foetus. ${ }^{36}$ This kind of twist makes the 
hearings more directly adversarial and adds an extra-statutory burden on the petitioning minor.)

Despite a petitioner's legal 'innocence', much of the existing structure and content of bypass hearings - the secrecy, the nature of the questions, the mandatory revelations - convey a sense of her wrongdoing. ${ }^{37}$ This point is not lost on minors. As one Massachusetts teenager explained after her hearing, 'I'm only 16 , and usually at this age, you know, you don't see people going to court for good things' ${ }^{38}$ And just what has she done wrong? I suggest that the bad behaviour takes three forms: her sexual activity; her decision to seek an abortion; and the defiance of parents in regard to both of these.

Each of these was once a matter for law to handle. Until the 1970s, parents regularly brought their sexually active daughters to the attention of the juvenile court. ${ }^{39}$ But reform schools and maternity homes are now institutions of the past. Disobedient teenagers are no longer physically detained; pregnant high-schoolers are no longer expelled; and abortion is legal. Female teenage sexuality, once subject to an array of sanctions, now sells Pepsi (or any other product). But while female teen sexuality has been relocated from juvenile court to billboards and kiosks, it has not been normalized. In contrast to social attitudes in such western European countries as France or Sweden, teenage sexual activity in the US is regarded as abnormal and problematic. Abstinence is the primary focus of federal government efforts (as well as those of many local school districts) for combating unplanned teenage pregnancies. ${ }^{40}$ Parental involvement statutes serve to reassert a form of legal authority over the sexual behaviour of daughters that was more clearly under parental control. State legislatures are clear about this: recall the explicit statutory purpose of 'protecting the rights of parents'. The Michigan legislature was even more explicit: its parental involvement statute is called the Parental Rights Restoration Act. ${ }^{41}$

And just how do such statutes restore parental rights? The intended connection between parental involvement and bypass hearings was set out by a justice of the Texas Supreme Court:

Although the state cannot prohibit minors from obtaining an abortion, it can and has created a rule of law sufficiently impressing upon minors the seriousness of the abortion decision and that the State wants the parents to be informed.... Once a minor becomes aware of what she must go through to obtain a judicial bypass, she will choose for herself to involve her parents. ${ }^{42}$

The idea seems to be that rather than undergo a judicial bypass hearing - that is, sneak off to court during school hours to discuss one's pregnancy, sexual history, and life plans with a middle-aged stranger girls will choose to talk to their parents, who will in turn persuade their 
daughters not to abort. While it is unclear that parents in general counsel against abortion, this is clearly the legislative expectation. ${ }^{43}$

This scheme - bypass hearing as threat - works only if the hearings are understood as a kind of ordeal. For girls who still refuse to involve parents, the hearings move from a threat to an experience. And the nature of the experience - humiliating, risky, intrusive - is properly understood as punishment. If some teenagers insist on aborting against the perceived wishes of their parents, bypass hearings at least make them pay a price for their decision.

\section{Policies and Politics}

Understanding the hearings as a means of imposing control over teenage sex and abortion helps explain why bypass statutes are so popular among legislatures despite the fact that so few petitions are denied. Bringing about actual conversations between parents and their daughters may not be the only or the most accurate measure of statutory success. To be sure, some girls will decide to talk to their parents on account of the requirement, and may well reach a more satisfying decision by virtue of that input and support. But in thinking about parental involvement, several factors are worth keeping in mind. The first concerns the nature of the required involvement. In general, the legislation demands neither conversation nor informed counselling, as required in several western European countries. The legal requirement in the US is a signature. Second, families who engage with one another in meaningful intergenerational ways are likely to have established lines of communication and trust before the arrival of an unplanned pregnancy. ${ }^{44}$ Finally, a few states require consent or notice to both parents and with no exemption for non-custodial parents. It is hard to see how involving two parents is intended to do anything but thwart the abortion plans of a teenager who has already talked to one parent. Indeed, after studying Minnesota's two parent rule, the US Supreme Court found that there was no justification for the requirement; a majority of the justices concluded nonetheless that the availability of a bypass hearing made up for the problem. ${ }^{45}$ By contrast, in order to increase the likelihood that pregnant minors will confide in some trusted adult, the state of Maine offers its pregnant minors two options. They can either get consent from a parent or another adult family member, or they can receive comprehensive counselling on pregnancy, abortion, adoption, and state support for child care from one of nine categories of authorized counsellors (including nurse, clergy, social worker, psychologist). ${ }^{46}$ Wisconsin similarly permits grandparents or aunts, uncles, and siblings over the age of 25 to consent. ${ }^{47}$

The popularity of parental involvement statutes is also due to the political capital they offer politicians who can suddenly be pro-life, pro-choice, and all pro-family all at once. Polls consistently show that 
even those who support abortion generally favour limiting it for teens. ${ }^{48}$ 'Pro-choice' politicians, such as Bill Clinton when Governor of Arkansas, regularly sign parental involvement legislation without apology or hesitation. Thus it may not matter that most bypass petitions are approved. At the level of symbolic politics, the statutes vindicate a moral position against teenage promiscuity and for parental authority. They represent law on the books that says in our state girls can't run around having sex and aborting their foetuses. As an expressive matter, the legislation is gratifying to legislators and constituents. To the extent that it actually may reduce the rate of teenage abortion - a difficult correlation to measure - all the better. ${ }^{49}$

Finally, thirty years after Roe $\mathrm{v}$ Wade and a decade after Casey, there are few areas of abortion regulation where there is much constitutional room to move: late term abortions and minors are about all that remain. In this regard, the enactment and stringent implementation of parental involvement laws offer an opportunity for legislators and judges to do something. In 1998, four justices of the Alabama Supreme Court characterized the Alabama's statute in just this way:

[I]t seems clear that the Legislature intended, in adopting the Parental Consent Statute, to preserve the life of the unborn, and that it deliberately was doing what it could within the constraints of the Federal Constitution, as interpreted by the SC of the United States, to accomplish that purpose. ${ }^{50}$

Yet as the Alabama judges acknowledge, abortion is legal in the United States, even for minors. The decision remains that of the pregnant girl, subject either to parental notice or a judicial determination of maturity. Judicial bypass hearings that provide anything less than a fair assessment of the minor's maturity or best interests seriously compromise her right to decide. Yet as I have suggested, it is not only the improper implementation of the hearings that is troubling but the purpose behind their enactment in the first place. Abortion is almost always a complex matter, whether at the level of private decision-making or of legal regulation. With regard to minors, complex questions of competency, counselling, contraception, social rights and familial support are all matters for research and careful policy debate and development. But these are not the issues at the heart of the discussion in the United States, where the focus is instead on preventing abortions. Parental involvement statutes have little to do with improving the quality of a minor's decision and much to do with dissuading her from abortion and punishing her if she proceeds. Giving vulnerable young women the option of confronting their parents or participating in a judicial bypass hearing may be good politics in the United States, but it is misguided family policy that discredits our collective better judgment. 


\section{NOTES}

${ }^{1}$ NARAL Pro-Choice America, Issue Brief: Minors' Access to Abortion Services, October 2002, available at http://www.prochoiceamerica.org/facts. In ten of the states, the laws have been held unconstitutional and are not being enforced. See discussion in note 11, below.

${ }^{2}$ Blum et al (1987), Zabin et al (1992), Lee (this volume);

${ }^{3}$ Alaska Code, 1997 Temporary and Special Acts, Ch. 14, § 1 .

${ }^{4}$ Planned Parenthood of Central Missouri v Danforth, 428 US 52 (1976).

${ }^{5}$ Roev Wade, 410 US 113 (1973).

${ }^{6}$ Planned Parenthood of Southeastern Pennsylvania v Casey, 505 US 833 (1992).

${ }^{7}$ For an overview, see Scott (2000).

${ }^{8}$ See In re Gault, 387 US 1 (1967).

${ }^{9}$ See Careyv Population Services, 431 US 678 (1977). In Carey, the state of New York had banned the sale of contraceptives to minors under 16 on the grounds that the ban 'furthered the State's policy against promiscuous sexual intercourse among the young'.

${ }^{10}$ Bellotti v Baird, 443 US 622, 642 (1979).

${ }^{11} 443$ US at 634. It is important to note that under some state constitutions, the privacy rights of minors are considered equal to those of adults, at least with regard to an abortion decision. Thus in Montana, New Jersey, and California, parental involvement statutes have been struck down as a matter of state privacy law. See, eg Planned Parenthood of Central New Jerseyv Farmer, 762 A.2d 620 (NJ 2000); North Florida Women's Health and Counseling Services v Florida, 866 So.2d 612 (Fla. 2003).

${ }^{12}$ Planned Parenthood of Central Missouri v Danforth, 428 US 52 (1976). For the argument that judges in bypass hearings are indeed exercising a veto over the pregnant minor's decision, see Guggenheim (2002).

${ }^{13} 443$ US at 647.

${ }^{14}$ Idem at 630 . The bypass hearing saves statutes which require parental consent, although the Court has never explicitly decided if a bypass hearing is required in cases where parents must only be notified, a lesser form of constraint. Almost every state that requires parental notification has, however, included a bypass procedure and the Court has affirmed several times that this satisfies any constitutional demands that might be implicated by notification statutes.

${ }^{15}$ To save minors one extra trip to the courthouse, some states have made the necessary forms, petitions, and instructions available on-line. See, eg State of Texas Judiciary On-Line, Parental Notification Forms, available at www.courts.state.tx.us/supreme/rules/pnr/pnrforms.pdf. On the question of why privacy is vital to many abortion patients in the United States, see Chapman (2003).

${ }^{16}$ Silverstein (1999) and Silverstein and Speitel (2002);

${ }^{17}$ Hodgson v Minnesota, 497 US 417 (1990).

${ }^{18}$ Planned Parenthood League of Massachusetts v Attorney General, 677 N.E.2d 101, 105 (Mass. 1997).

${ }^{19}$ Planned Parenthood of Central New Jersey v Farmer, 762 A.2d 620 (NJ 2000).

${ }^{20}$ For a thorough analysis of the politics of abortion campaign strategies and rhetoric, see generally Saletan (2003).

${ }^{21}$ Hodgson v Minnesota, 497 US 417, 436 (1990); Mlyniec (1996).

${ }^{22}$ In re Anonymous, 684 So.2d 1337 (Ala. Civ. App. 1996).

${ }^{23}$ Bonavoglia (1988).

${ }^{24}$ In re Complaint of Jane Doe, 613 N.E.2d 1112 (Ohio App. 1993).

${ }^{25}$ In re Anonymous, 515 So.2d 1254 (Ala. Civ. App. 1987).

${ }^{26}$ See, eg American Academy of Pediatricians, Committee on Adolescence (1996).

${ }^{27}$ In re Jane Doe, 19 S.W.3d 346, 355 fn 11 (Tex. 2000).

${ }^{28} 19$ S.W.3d at 354.

${ }^{29}$ For an excellent interview study of bypass petitioners in Massachusetts, see Ehrlich (2003).

${ }^{30}$ Ehrlich (2003:127-9). On what parents don't know, see Schemo (2002) at A20.

${ }^{31}$ In Casey, the statute at issue required married women to notify their husbands before getting an abortion. After reviewing the evidence on domestic violence, the Court reasoned that abusive husbands might intimidate or physically prevent their pregnant wives from seeing a doctor and struck down the spousal notice requirement. Because minors have less power and independence than wives, their concerns about punishment and obstruction would seem at least reasonable as those of adult women. The Court has found, however, that the bypass process offers them an 
adequate alternative. For a detailed comparison of the treatment of adults and minors in Casey, see Bermen (1994).

${ }^{32}$ For consideration of the constitutional dimensions of compelled speech and its relation to the values of sincerity and belief, see Blasi and Shiffrin (2004).

${ }^{33}$ See Sollinger (1993)

${ }^{34}$ See Margalit (1996).

${ }^{35}$ In re Jane Doe II, 19 S.W.3d 346, 358 (Tex. 2000).

${ }^{36}$ See generally Silverstein (2001).

${ }^{37}$ For an analysis of how bypass hearings work performatively to punish pregnant teenagers, see Sanger (forthcoming).

${ }^{38}$ Ehrlich, above note 29 , at 143.

${ }^{39}$ See Odem (1995), Devlin (1997), and Hicks (2003).

${ }^{40}$ Boonstra (2002).

${ }^{41}$ Parental Rights Restoration Act, Michigan Comp. Laws Annotated § 722.901 - 908 (West 2003).

${ }^{42}$ Jane Doe (II), 19 S.W.3d 346, 363 (concurring opinion).

${ }^{43}$ In a 1991 study of pregnant minors who had abortions in states without parental involvement laws, 63 per cent of mothers believed, upon first learning about the pregnancy, that the daughter should have an abortion; this figure rose to 93 per cent in favour of abortion by the time of the abortion (Henshaw and Kost, 1992).

${ }^{44}$ See Blum et al (1987), Zabin et al (1992), and Lee (this volume). One study has shown that family adaptability or the ability of parents to adjust in relation to situation stress is the most important variable in assessing when minors in bypass states choose to talk about their intended abortions. See Griffin-Carlson and Schwanenflugel (1998).

${ }^{45}$ Hodgson v Minnesota, 497 US 417, 436 (1990). In contrast, the Massachusetts SC struck down that state's two parent requirement on the grounds that the state's interests were sufficiently served by the involvement of one parent. Planned Parenthood League of Massachusetts v Attorney General, 677 N.E.2d 101, 108 (Mass. 1997).

${ }^{46}$ Maine Revised Statutes Annotated, tit. 22, § 1597-a (West 1992).

${ }^{47}$ Wisconsin Statutes Annotated $§ 48.375$ (West 1992).

${ }^{48}$ Saletan (2003: 139).

${ }^{49}$ The correlation is difficult because the abortion rate for women and minors has been falling generally and because some minors can travel to states without parental involvement statutes for an abortion (Hershaw, 1995).

${ }^{50}$ Justin Hooper, Maddox, See, and Lyons (concurring specially in part and dissenting in part), In re Anonymous, 720 So.2d 497, 502-03 (Ala. 1998).

\section{REFERENCES}

American Academy of Pediatricians, Committee on Adolescence (1996) 'The adolescent's right to confidential care when considering abortion', 97 Pediatrics 746-51.

Bermen, L. (1994) 'Planned parenthood v casey: supreme neglect for unemancipated minors' abortion rights', 37 Howard Law Journal 577-604.

Blasi, V. and Shiffrin, S. (2004) 'The story of West Virginia State Board of Education v Barnette', in M. Dorf (ed) Constitutional Law Stories 433-75, New York: Foundation Press,.

Blum, R., Resnick, M. and Stark, T. (1987) 'The impact of a parental notification law on adolescent decision-making', 77 American Journal of Public Health 619-20.

Bonavoglia, A. (April 1988) 'Kathy's day in court', Ms Magazine 46-52.

Boonstra, H. (2002) 'Issues in brief, teen pregnancy: Trends and lessons learned', 5 The Alan Guttmacher Institute 1, 1-4.

Chapman, A. (2003) 'Privacy rights and abortion outing: A proposal for using common-law torts to protect abortion patients and staff', 112 Yale Law Journal 1545-53.

Devlin, R. (1997) 'Female juvenile delinquency and the problem of sexual authority in America, 1945-1965', 9 Yale Journal of Law and Humanities 147-82

Ehrlich, J. S. (2003) 'Grounded in the reality of their lives: listening to teens who make abortion decisions without involving their parents', 18 Berkeley Women's Law Journal 61-180. 
Guggenheim, M. (2002) 'Minor rights: the adolescent abortion cases', 30 Hofstra Law Review 589-646.

Henshaw, S. and Kost, K. (1992) 'Parental involvement in minors' abortion decisions', 24 Family Planning Perspectives, 196-213.

Hershaw, S. (1995) 'The impact of requirements for parental consent on minors' abortions in Mississippi, 27 Family Planning Perspectives, 120-2.

Hicks, C. (2003) 'In danger of becoming morally depraved: Single black women, working class families, and New York state's wayward minor laws, 1917-1928', 151 University of Pennsylvania Law Review 2077-2121.

Margalit, A. (1996) The Decent Society, Cambridge, Mass.: Harvard University Press.

Mlyniec, W. (1994) 'A judge's ethical dilemma: assessing a child's capacity to choose', 64 Fordham Law Review 1873.

Odem, M. (1995). Delinquent Daughters: Protecting and Policing Adolescent Female Sexuality in the United States, 1885-1920, Chapel Hill, NC: University of North Carolina Press.

Saletan, W. (2003) Bearing Right: How the Conservatives Won the Abortion War, Berkeley, CA: University of California Press.

Sanger, C. (forthcoming) Compelling Narrative: Judicial Bypass Hearings and the Misuse of Law.

Schemo, D. 'Study finds mothers unaware of children's sexual activity', New York Times 5 September 2002.

Schwanenflugel, P. (1998) 'Adolescent abortion and parental notification: evidence of the importance of family functioning on the perceived quality of parental involvement in us families', 39 Journal of Child Psychology and Psychiatry 543-53.

Scott, E. (2000) 'The legal construction of adolescence', 29 Hofstra Law Review, 547-98.

Silverstein, H. (1999) 'Road closed: evaluating the judicial bypass provision of the Pennsylvania abortion control act', 24 Law and Social Inquiry, 73-96.

Silverstein, H. (2001) 'In the matter of anonymous, a minor: Fetal representation in hearings to waive parental consent for abortion', 11 Cornell Journal of Law and Public Policy, 69-111.

Silverstein, H. and Speitel, L. (2002) “ "Honey, I have no idea”: Court readiness to handle petitions to waive parental consent for abortion', 88 Iowa Law Review 75-120.

Solinger, R. (1993) 'A complete disaster: Abortion and the politics of hospital abortion committees, 1950-1970', 19 Feminist Studies 241-68.

Zabin, L., Hirsch, M., Emerson, M. and Raymond, E. (1992) 'To whom do inner-city minors talk about their pregnancies? Adolescents' communication with parents and parent surrogates', 24 Family Planning Perspectives 148-54. 